\title{
From Fibrinolysis to the Plasminogen-Plasmin System and Beyond: A Remarkable Growth of Knowledge, with Personal Observations on the History of Fibrinolysis*
}

\author{
Hau C. Kwaan, MD, FRCP ${ }^{1}$ \\ ${ }^{1}$ Division of Hematology/Oncology, Feinberg School of Medicine, and \\ the Robert H. Lurie Comprehensive Cancer Center, Northwestern \\ University, Chicago, Illinois
}

Address for correspondence Hau C. Kwaan, MD, FRCP, Room 8258, Olson Pavilion, 710 North Fairbanks Court, Chicago, IL 60611, (e-mail: h-kwaan@northwestern.edu).

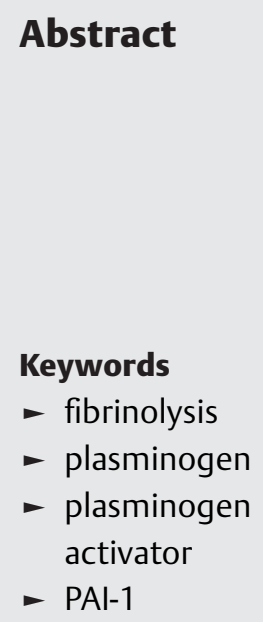

Great advances have been made in our understanding of the fibrinolytic system from the initial discovery of proteolysis of fibrin by plasmin to the multifaceted and complex role of the plasminogen-plasmin (P-P) system. We now know that the P-P system is composed of several serine proteases and their inhibitors (serpins). This system is involved in many physiological functions, including embryogenesis, cell migration, and wound healing. They also play an important role in the pathogenesis of many diseases, including atherosclerosis, obesity, cancer, and even autoimmune disorders, and neuronal degeneration. Knowledge of their role in cancer enables their use as a prognostic factor. Therapeutic use of various forms of proteases derived from this system has been employed as thrombolytic agents. In addition, small molecules designed to inhibit many of the components of the P-P system are now available for clinical trial, aimed at treatment of these various disorders. The history of such remarkable development of our knowledge on fibrinolysis is reviewed in this article.

Among the many advances in our understanding of the various physiologic phenomena, few can match that of fibrinolysis. This is the process in which a fibrin clot is removed by the body when its hemostatic function is completed. The fibrinolytic system plays an important role in many of the physiologic functions of the body as well as in the pathogenesis of many diseases. Our knowledge of this system, also known as the plasminogen-plasmin system (P-P system), has made enormous advances from regulation of hemostasis to the pathogenesis of a wide range of diseases including atherosclerosis, obesity, cancer, and even autoimmune disorders, as well as neuronal degeneration. New findings recently obtained have enormous therapeutic implications. Components of the fibrinolytic system can be selectively

* This article is dedicated to my mentor Alexander J. S. McFadzean, FRCP, who started it all for me.

published online July 7,2014
Issue Theme A Short History of Thrombosis and Hemostasis: Part I (40th Year Celebratory Issue); Guest Editor, Emmanuel J. Favaloro, PhD, FFSC (RCPA). targeted by new inhibitors. On the 40th anniversary of Seminars in Thrombosis $\mathcal{E}$ Hemostasis, it seems appropriate to provide our readers with a historical overview of this remarkable development, along with some interesting personal observations and an outlook into the enormous translational potential of this system.

\section{Early Observations}

\section{Postmortem Fibrinolysis}

This phenomenon was first observed in postmortem blood by both Morgagni ${ }^{1}$ in 1769 and later John Hunter ${ }^{2}$ in 1794. The latter wrote:

In many modes of destroying life the blood is deprived of its power of coagulation, as happens in sudden death produced by many kinds of fits, by anger, electricity or
Copyright $\odot 2014$ by Thieme Medical Publishers, Inc., 333 Seventh Avenue, New York, NY 10001, USA.

Tel: +1(212) 584-4662.
DOI http://dx.doi.org/ 10.1055/s-0034-1383545. ISSN 0094-6176. 
lightning; or by a blow on the stomach, etc. In these cases we find the blood, after death, not only as fluid a state as in the living vessels, but it does not even coagulate when taken out of them.

Virchow noted that "capillary blood in the cadaver was always fluid and incoagulable and that the blood in the veins was more often than not incoagulable." From this astute observation, he hypothesized that liquefaction of blood originated from the endothelium. ${ }^{3}$ Morawitz observed that in sudden death, there was no fibrinogen in the blood, that such blood contained a lysin that could destroy the fibrinogen and fibrin in normal human blood. ${ }^{4}$ Yudin made use of these discoveries and published the results of transfusion of cadaver blood in Russia in 49 clinical cases by selecting subjects that died from sudden death. ${ }^{5}$ Blood was collected without preservatives from the jugular vein to avoid the infected mesenteric blood and could be stored in the refrigerator for up to 4 weeks. He and his assistants Skundina and Rusakov were able to observe the process of fibrinolysis in postmortem blood under a microscope.

\section{In Vitro Observations}

In 1838 , Denis observed that blood collected by wet-cupping first clotted and then spontaneously dissolved in 12 to 24 hours. $^{6}$ In 1887, Green noted that fibrin disintegrated in saline without obvious bacterial action. ${ }^{7}$ In 1893 , the term "fibrinolysis" was first given by Dastre, ${ }^{8}$ who noted that the process was a source of error in the measurement of fibrin in plasma. With dog's blood, he found an average loss of $8 \%$ in weight of fibrin on incubation for 18 hours. While many investigators were pursuing the isolation of the enzyme "fibrinolysin" from the plasma, ${ }^{9-11}$ Tillet and Gardner made a notable contribution by observing that a filtrate from streptococcus could activate the process of fibrinolysis and went on to isolate the enzyme streptokinase (SK). ${ }^{12}$ Milstone showed that the globulin fraction of plasma could produce fibrinolysis. ${ }^{13}$ Kaplan and later Christensen and McLeod found that this protein is inactive itself, but it is the precursor of the protease. The precursor of this was then termed plasminogen and the active enzyme plasmin. ${ }^{14-16}$ Biochemical studies led to discovery of plasminogen activators (PAs). They are naturally occurring within our bodies as tissue plasminogen activator (tPA) and urokinase, also known as urokinase-type plasminogen activator (uPA). They are also found in bacteria, such as SK in $\beta$-hemolytic streptococcus and staphylokinase in staphylococcus, and in other animals, such as desmoteplase in the vampire bat saliva. They were put to therapeutic use for thrombolysis, with SK being first used to break down fibrinous pleural adhesions in $1949^{17}$ and in acute myocardial infarction. ${ }^{18}$

\section{In Vivo Observations}

Many studies were performed during this period in experimental animals, showing that fibrinolytic activity can be induced by anaphylactic shock, ${ }^{19,20}$ severe hemorrhage, ${ }^{21}$ and electric convulsion. ${ }^{22}$ In man, increased fibrinolytic activity was found during surgical operations, ${ }^{23,24}$ severe hemorrhage, ${ }^{21,23}$ strenuous exercise, and the injection of adrenaline. $^{25}$ It was believed that adrenaline might have been responsible, as conditions such as alarming suggestions under hypnosis, anxiety in students about to take part in examinations, and patients awaiting gastroscopy, could all induce fibrinolysis. The finding that excessive fibrinolysis could cause major clinical bleeding was observed in many disorders, and was referred to as "fibrinolytic purpura." ${ }^{26}$ It was seen in transfusion reactions, ${ }^{27}$ severe burns, ${ }^{28}$ metastatic carcinoma of the prostate, ${ }^{29}$ obstetrical complications such as abruption placentae and amniotic fluid embolism, ${ }^{30-33}$ and in many types of surgical operations, ${ }^{33-35}$ some complicated with fatal intraoperative hemorrhage. In liver diseases, spontaneous plasma fibrinolysis was first noted by Goodpasture. ${ }^{36}$ He devised a simple test for fibrinolysis by observing the dissolution of a clot formed from recalcified blood over 24 hours. This "Goodpasture test" was used for many years in North America. Soon after, Ratnoff confirmed presence of fibrinolytic activity in cirrhosis but not in acute hepatitis. ${ }^{37}$

\section{Personal Observations}

My introduction to this topic was serendipitous. In 1955 , while performing the one-stage thrombin time, using Quick original method, as part of the work up of a cirrhotic patient with massive intraoperative hemorrhage, I encountered difficulty in obtaining the end point. A thin wisp of fibrin was formed but quickly disappeared under my eyes. Such was the dramatic effect of the excessive fibrinolysis activated by surgery in cirrhosis, ${ }^{38,39}$ thus confirming observations by others. ${ }^{36,37}$ As the origin of the fibrinolytic activity was unknown at the time, we used direct approaches studying venous blood in vivo in man and found that fibrinolytic activity could be released from veins after various stimuli. ${ }^{40,41}$ Likewise, similar results were found in experimentally induced venous thrombi in rabbits. ${ }^{42}$ As discussed earlier, Virchow, by noting that blood in small blood vessels was more likely fluid and incoagulable than blood collected from larger vessels, ${ }^{3}$ had suspected that blood vessels were the origin of fibrinolysis. But our findings were the first direct observation that fibrinolytic activity was derived from veins.

Several interesting aspects of our studies are noteworthy. First, we observed that stimulation of one venous segment could release fibrinolytic activity from another vein located far from the site of stimulation, indicating that the stimulus could be transmitted via perivascular sympathetic nerves. ${ }^{41}$ At the time, we were mystified and had no other explanation for this phenomenon. Some 50 years later, Jim O'Rourke came to me at a meeting and excitedly told me that he had demonstrated that the perivascular sympathetic pathway was indeed responsible for this signal transmission. ${ }^{43,44}$

In our studies on animals, experimentally induced venous thrombi were produced in the marginal veins of rabbit's ears. ${ }^{42}$ Parallel studies using these stimuli were done using the lysis of the thrombi as the end point. The findings verified that we had the ones observed in the human veins. ${ }^{42,45}$ 


\section{Next Five Decades (1960-2010)}

While Astrup and his coauthors were able to show the amounts of PA in different organs by extraction, ${ }^{46-54}$ the pursuit of knowledge soon turned to finding components of the P-P system at the cellular level. A fibrin slide method for histologic localization was first designed by Todd, ${ }^{55}$ who used a modification of Astrup fibrin plate method for pinpointing areas of lysis in histologic sections. With this method, fibrinolytic activity was localized to the endothelium in both normal $^{56-59}$ and pathologic tissues. ${ }^{60-63}$ It appeared that the activity was most intense in young regenerating endothelial cells, as shown in newly formed capillaries growing with granulation tissues, ${ }^{59}$ in revascularized myocardium following infarction ${ }^{60}$ and in coronary atherosclerotic lesions. ${ }^{62}$ These findings were subsequently confirmed by more sophisticated methods such as in situ hybridization.

Using cell cultures in vitro, studies of the PAs from various cells were made to determine their function in physiology and in pathology. ${ }^{64}$ These studies revealed that fibrin is not the sole substrate for plasmin. As a protease, plasmin can break down extracellular matrix, thereby enabling cell movements. Plasmin can also activate latent metalloproteinases. Thus, plasmin participates in a wide range of processes that involve cell migration. As the role of plasmin is not limited to the lysis of fibrin, the fibrinolytic system is more appropriately referred to as the P-P system. ${ }^{65}$ This period of development is also noted for the discovery of other members of the P-P system, ${ }^{65,66}$ including cell surface receptor for UPA (UPAR), ${ }^{67}$ for tPA, known as annexin $A 2^{68-70}$ as well as a surface protein S-100A10 that is colocalized on the cell surface with receptors for plasminogen. ${ }^{71,72}$ In addition, the inhibitors of fibrinolysis were also identified, including several PA inhibitors (PAI), ${ }^{73-76}$ of which PAI-1 has an especially important biological role. The present day concept of the P-P system is shown in - Fig. 1.

Through the proteolytic action of plasmin, the P-P system was found to be regulating many physiologic processes,

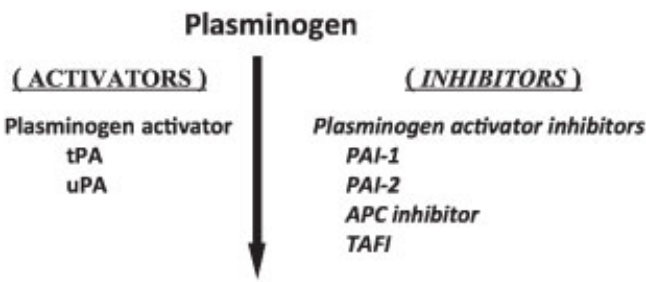

Degradation of fibrin
$\begin{aligned} & \text { Degradation of } \\ & \text { extracellular matrix }\end{aligned}$
$\begin{aligned} & \text { Activation of growth } \\ & \text { factors }\end{aligned}$ $\begin{aligned} & \begin{array}{l}\text { Plasmin inhibitors } \\ \alpha 2 \text {-antiplasmin } \\ \alpha 2 \text {-macroglobulin } \\ \text { TAFI } \\ \text { serine protease inhibitors } \\ \text { (AT, } \alpha 2 \text {-antitrypsin, etc.) }\end{array} \\ & \text { (A) }\end{aligned}$

Fig. 1 The present day concept of the plasminogen-plasmin system. The factors listed on the left are activators and those on the right (in italics) are inhibitors, kept in balance under physiologic conditions. APC, activated protein C; AT, antithrombin; PAI, plasminogen activator inhibitor; TAFI, thrombin-activable fibrinolysis inhibitor; tPA,

plasminogen activator; uPA, urokinase-type plasminogen activator. including embrogenesis, ${ }^{77}$ ovulation, ${ }^{78,79}$ neuron growth, ${ }^{80,81}$ brain function, ${ }^{82-84}$ catecholamine secretion, ${ }^{85}$ activation of inflammatory cells, ${ }^{86}$ wound healing, ${ }^{87,88}$ and skeletal muscle regeneration. ${ }^{89}$ Notable advances were made in linking the function of this system with the pathogenesis of a wide range of diseases, among which are cancer ${ }^{90-92}$ and vascular diseases. ${ }^{93}$ Many new thrombolytic agents were also developed. ${ }^{94,95}$ Much information was made available in several reviews ${ }^{65,96}$ including an issue of the Seminars of Thrombosis $\mathcal{E}$ Hemostasis in $1991^{97}$ and more recently in $2013 .^{98}$ In the following sections, progress in several of these developments has been selected to be reviewed in greater depth.

\section{Cancer}

The earliest observation of association of fibrinolysis and cancer was made by Carrel and Burrows, who observed liquefaction of growth media by malignant tumors, ${ }^{99}$ whereas clinical record of fibrinolytic bleeding was made by Tagnon et al in patients with metastatic carcinoma of prostate. ${ }^{29}$ Evidence of a possible causative role of PA in malignancy was shown by the sharp increase in fibrinolytic activity in viral transformed fibroblasts. ${ }^{100}$ This PA was identified by Astedt and Holmberg as uPA. ${ }^{101}$ Subsequently, uPA, uPAR, and PAI-1 were also found by tissue extraction, immunohistochemical staining, and in situ hybridization to be greatly increased in many forms of cancer. These include cancer of the breast, stomach, colon and rectum, esophagus, pancreas, glioma, lung, kidney, prostate, uterine cervix, ovary, liver, and bone. ${ }^{92,100,102}$ The P-P system participates in multiple steps in cancer from carcinogenesis to growth and metastasis. ${ }^{92,103,104}$ The complex interactions involved in these processes are beyond the scope of this article.

The levels of UPA, UPAR, and PAI- 1 have been found to be correlated to the aggressiveness and the metastatic potential of many tumors both in tumor cell cultures and in tumor tissues. $^{104,105}$ These are used as biomarkers in the risk stratification of several cancer, especially in carcinoma of breast. Higher levels of uPA and PAI-1 are associated with worse prognosis in carcinoma of breast. ${ }^{106-109}$ The incorporation of the uPA/PAI-1 status into the treatment algorithms has been shown to be helpful in deciding which patients can be spared from the more aggressive chemotherapy. ${ }^{110}$ Clinical validation of the usefulness of these biomarkers are currently being performed in other types of cancer as well. ${ }^{104,105,111-113}$ In carcinoma of pancreas, the postoperative survival of those with high expression of UPA and UPAR was 9 months compared with 18 months in those without expression of both markers or of only one marker. ${ }^{114}$ In small cell carcinoma of lung, those with high levels of uPAR predicted poor response to chemotherapy. ${ }^{115}$ More studies are needed to verify the clinical utility of these biomarkers.

The use of inhibitors in retarding tumor growth has some successes in experimental animals. For example, transfection of PAI- 1 to prostate cancer cells impaired growth and metastasis in mice. ${ }^{116}$ Anti-uPAR antibody blocks prostate cancer invasion, migration, growth, and experimental skeletal metastasis in vitro and in vivo. ${ }^{117}$ The development of drugs 
targeting uPA, uPAR, and PAI-1 has become an exciting area of investigation. A wide spectrum of monoclonal antibodies, targeted toxins, synthetic small molecules and peptides, and antisense molecules are now known to have antitumor effects in human cancer. Several promising drugs include a small molecule targeting the active site in the S1 pocket of uPA. This agent, known as WX 671, has antitumor activity in carcinoma of head and neck, ${ }^{118}$ pancreatic carcinoma, ${ }^{119}$ and carcinoma of breast. ${ }^{120}$ Hopefully in the near future, more agents will become available, and prove to be effective as anticancer agents.

\section{Thrombolysis}

The earliest thrombolytic agent was SK, an activator of plasminogen. ${ }^{12,17,121,122}$ It was first used to breakdown fibrinous pleural exudates. ${ }^{17}$ This same agent was then employed in thrombolysis of experimental clots in rabbits, ${ }^{123}$ and SK-activated plasmin (also known as "fibrinolysin") was subsequently used to lyse experimental venous and arterial thrombi in animals. ${ }^{124,125}$ In man, SK-activated plasmin was found to be effective in lysis of thrombi in several clinical studies. $^{18,126-128}$ One notable study was performed on human volunteers, in whom experimental thrombi were produced by a dental broach in an arm vein, ${ }^{129}$ a feat unlikely to be repeated today.

The delivery of the thrombolytic agents was for many years performed by the intravenous route. Before long, this method was found to be problematic, as the plasmin was rapidly inhibited by the circulating antiplasmin. The next phase was the development of several PAs, including tPA and uPA. Again, their therapeutic life span was short lived as they are also promptly inhibited by PAI- 1 and antiplasmin. The inhibition, however, can be reduced if the agent is rapidly bound to the fibrin thrombus thereby improving its thrombolytic efficacy. ${ }^{94}$ Many mutants of recombinant tPA were developed to improve these pharmacologic features. Successful thrombolysis depends on age and content of the thrombus, and accessibility of the thrombolytic agent. One notable example for the importance of early thrombosis is that of ischemic stroke, with convincing evidence that brain function restoration occurs only in early lysis within 3 hours. ${ }^{130-132}$

To circumvent the inhibitors of fibrinolysis, the thrombolytic agents can be delivered by a catheter directly to the thrombus. Direct delivery of thrombolytic agents to the occluded coronary artery was first performed by Boucek and Murphy in $1960^{132}$ and in peripheral arterial thrombosis by Dotter in $1974 . .^{133}$ The practice today uses improved techniques such as percutaneous endovascular insertion of a catheter advanced to the site of the thrombus, under direct radiologic imaging. The catheter can be left in place for a slow delivery of the agent. ${ }^{134,135}$ Catheter-directed thrombolysis can also be performed in conjunction with thrombectomy or with high-frequency low-intensity ultrasound waves to accelerate clot dissolution by dissociating the fibrin strands. ${ }^{135}$ Today, the indications for thrombolysis cover practically all forms of thrombi. Further discussion of this topic is beyond the scope of this article.

\section{Inhibitors of PAI-1 as New Drug Target}

Among the various components of the P-P system, PAI- 1 has been found to be involved in the pathogenesis of a variety of disorders. ${ }^{136-139}$ These include thrombotic disorders, cancer, metabolic syndrome and obesity, polycystic ovarian disease, alopecia, pulmonary fibrosis, nephrosclerosis, and myelofibrosis. It is also implicated in aging and Alzheimer disease. Thus, intensive efforts are being performed in the search for an inhibitor of PAI-1. Both neutralizing monoclonal antibodies against PAI- $1^{140}$ and small peptide molecules ${ }^{141,142}$ have been developed. Their clinical activities are yet to be determined.

\section{Conclusion}

Since the observations of postmortem fibrinolysis over two centuries ago, our understanding of the fibrinolytic system has evolved immensely. From having a limited function of dissolution of a fibrin clot, the components of the P-P system are now known to be involved in many physiologic and pathologic processes. Such knowledge has enabled the development of effective treatment of many thrombotic disorders. It will be of great interest to watch further development of new drugs based on our increasing knowledge of the action of the components of this system, in particular of PAI- 1 .

\section{References}

1 Morgagni GB. Founders of Modern Medicine: Giovanni Battista Morgagni. (1682-1771). Med Library Hist J 1903;1:270-277

2 Hunter J. A treatise on the blood, inflammation, and gun-shot wounds, by the late John Hunter. To which is prefixed, A short account of the author's life, by his brother-in-law, Everard Home. London printed by John Richardson, for George Nicol; 1794

3 Virchow R. Die cellularpathologie 1871:194

4 Morawitz P. Uber einige post-mortale blutveranderunguen. Beitr z chem Physiol u Path 1906;8:1-10

5 Yudin SS. Transfusion of cadaver blood. J Am Med Assoc 1936; 106:997-999

6 Denis P. Essai sur l'application de la chimie a l'etude physiologique du sang de l'homme, et a l'etude physiologico-pathologique, hygienique et therapeutiques de maladies de cette humeur. Paris Bechet jne; 1838

7 Green JR. Note on the Action of Sodium Chloride in dissolving Fibrin. J Physiol 1887;8(6):372-377

8 Dastre A. Fibrinolyse dans le sang. Arch de physiol norm et path 1893;5:661-663

9 Hedin SG. On the presence of a proteolytic enzyme in the normal serum of the ox. J Physiol 1903;30(2):195-201

10 Opie EL, Barker BI. Leucoprotease and anti-leucoprotease of mammals and of birds. J Exp Med 1907;9(2):207-221

11 Sur RF. les proteinases contenues dans la fraction "acidglobulines" de divers plasma. Schweiz Med Wochenschr 1942; 72:156-172

12 Tillett WS, Garner RL. The Fibrinolytic Activity of Hemolytic Streptococci. J Exp Med 1933;58(4):485-502

13 Milstone JH. A factor in normal human blood which participates in streptococcal fibrinolysis. J Immunol 1941;42:109-116

14 Kaplan MH. Nature and role of the lytic factor in hemolytic streptococcal fibrinolysis. Proceedings of the Society of Experimental Biology,New York1944;57:40-50 
15 Christensen LR. Streptococcal Fibrinolysis: A Proteolytic Reaction Due to a Serum Enzyme Activated by Streptococcal Fibrinolysin. J Gen Physiol 1945;28(4):363-383

16 Christensen LR, Macleod CM. A Proteolytic Enzyme of Serum: Characterization, Activation, and Reaction with Inhibitors. J Gen Physiol 1945;28(6):559-583

17 Tillett WS, Sherry S. The effect in patients of streptococcal fibrinolysin and streptococcal desoxyribonuclease on fibrinous, purulent, and sanguinous pleural exudations. J Clin Invest 1949; 28:173-190

18 Fletcher AP, Alkjaersig N, Smyrniotis FE, Sherry S. The treatment of patients suffering from early myocardial infarction with massive and prolonged streptokinase therapy. Trans Assoc Am Physicians 1958;71:287-296

19 Imperati L. Contributo sperimentale alla interprezione del mechanismo causale fibrinolisi post-opertoria. Rivdi patsper 1939; 23:313-316

20 Rocha e silva M, Andrade SO, Teixeira RM. Fibrinolysis in peptone and anaphylactic shock in the dog. Nature 1946;157:801

21 Tagnon HJ, Levenson SM et al. The occurrence of fibrinolysis in shock, with observations on the prothrombin time and the plasma fibrinogen during hemorrhagic shock. Am J Med Sci 1946;211:88-96

22 Fantl P, Simon SE. Fibrinolysis following electrically induced convulsions. Aust J Exp Biol Med Sci 1948;26(Pt. 6):521-529

23 Macfarlane RG. Fibrinolysis following operation. Lancet 1937; i: $10-12$

24 Truelove SC. Fibrinolysis and eosinopenia after surgical operations. Clin Sci (Lond) 1952;11(2):107-112

25 Biggs R, MacFARLANE RG, Pilling J. Observations on fibrinolysis; experimental activity produced by exercise or adrenaline. Lancet 1947;1(6448):402-405

26 Stefanini M. Fibrinolysis and "fibrinolytic purpura." Blood 1952; 7(10):1044-1046

27 Crosby WH, Stefanini M. Pathogenesis of the plasma transfusion reaction with especial reference to the blood coagulation system. J Lab Clin Med 1952;40(3):373-386

28 Ungar G, Damgaard E. Protein breakdown in thermal injury. Proc Soc Exp Biol Med 1954;87(2):378-383

29 Tagnon HJ, Schulman P, Whitmore WF, Leone LA. Prostatic fibrinolysin; study of a case illustrating role in hemorrhagic diathesis of cancer of the prostate. Am J Med 1953;15(6):875-884

30 Moloney WC, Egan WJ, Gorman AJ. Acquired afibrinogenemia in pregnancy. N Engl J Med 1949;240(15):596-598

31 Weiner AE, Reid DE, Roby CC. Coagulation defects associated with premature separation of the normally implanted placenta. Am J Obstet Gynecol 1950;60(2):379-386

32 Dieckmann WJ. Blood chemistry and renal function in abruptio placentae. Am J Obstet Gynecol 1936;31:734-745

33 Coon WW, Hodgson PE. Fibrinolysis in surgery patients. I. Possible relationship to a hemorrhagic diathesis. Surg Gynecol Obstet 1952;95(6):717-724

34 Cliffton EE, Grossi C, Siegel M. Hemorrhage during and after operation secondary to changes in the clotting mechanism; physiology and methods of control. Surgery 1956;40:37-51; discussion, 51-53

35 Ratnoff OD. Studies on a proteolytic enzyme in human plasma. VII. A fatal hemorrhagic state associated with excessive plasma proteolytic activity in a patient undergoing surgery for carcinoma of the head of the pancreas. J Clin Invest 1952;31(5):521-528

36 Goodpasturl EW. Fibrinolysis in chronic hepatic insufficiency. Bull Johns Hopkins Hosp 1914;25:330-336

37 Ratnoff OD. Studies on a proteolytic enzyme in human plasma; the rate of lysis of plasma clots in normal and diseased individuals, with particular reference to hepatic diseases. Bull Johns Hopkins Hosp 1949;84(1):29-42

38 Kwaan HC, McFadzean AJ. Plasma fibrinolytic activity in cirrhosis of the liver. Lancet 1956;270(6929):968-969
39 Kwaan HC, McFadzean AJ, Cook J. On plasma fibrinolytic activity in cryptogenetic splenomegaly. Scott Med J 1957;2(4):137-150

40 Kwaan HC, Lo R, McFadzean AJ. The production of plasma fibrinolytic activity in vivo by serotonin (5-hydroxytryptamine) creatinine sulphate. Clin Sci (Lond) 1957;16(2):255-259

41 Kwaan HC, Lo R, McFadzean AJ. On the production of plasma fibrinolytic activity within veins. Clin Sci (Lond) 1957;16(2): 241-253

42 Kwaan HC, Lo R, Mcfadzean JS. On the lysis of thrombi experimentally produced within veins. Br J Haematol 1958;4(1):51-62

43 O'Rourke J, Jiang X, Hao Z, Cone RE, Hand AR. Distribution of sympathetic tissue plasminogen activator (tPA) to a distant microvasculature. J Neurosci Res 2005;79(6):727-733

44 Hao Z, Guo C, Jiang X, et al. New transgenic evidence for a system of sympathetic axons able to express tissue plasminogen activator (t-PA) within arterial/arteriolar walls. Blood 2006;108(1): 200-202

45 Kwaan HC, McFadzean AJ. The inhibition of clot lysis by corticotrophin. Lancet 1956;270(6908):136-137

46 Astrup T. The biological significance of fibrinolysis. Lancet 1956; 271(6942):565-568

47 Astrup T. Fibrinolysis in the organism. Blood 1956;11(9): 781-806

48 Astrup T, Sterndorff I. Fibrinolysokinase activity in animal and human tissue. Acta Physiol Scand 1956;37(1):40-47

49 Astrup T. Fibrinolysis. Acta Haematol 1952;7((5):):271-280

50 Astrup T, Sterndorff I. Fibrinolytic activity of tissue extracts and of trypsin. Nature 1952;170(4336):981

51 Astrup T, Stage A. Isolation of a soluble fibrinolytic activator from animal tissue. Nature 1952;170(4335):929

52 Astrup T, Albrechtsen OK. Estimation of the plasminogen activator and the trypsin inhibitor in animal and human tissues. Scand J Clin Lab Invest 1957;9(3):233-243

53 Albrechtsen OK. The fibrinolytic activity of human tissues. Br J Haematol 1957;3(3):284-291

54 Albrechtsen OK. The fibrinolytic activity of animal tissues. Acta Physiol Scand 1957;39(2-3):284-290

55 Todd AS. The histological localisation of fibrinolysin activator. J Pathol Bacteriol 1959;78:281-283

56 Kwaan HC, Astrup T. Localization of Fibrinolytic Activity in the Eye. Arch Pathol 1963;76:595-601

57 Kwaan HC, Astrup T. Demonstration of cellular fibrinolytic activity by the histochemical fibrin slide technique. Lab Invest 1967; 17(2):140-145

58 Kwaan HC, Cocco A, Mendeloff AI, Astrup T. Fibrinolytic activity in the normal and inflamed rectal mucosa. Scand J Gastroenterol 1969;4(5):441-445

59 Kwaan HC, Astrup T. Fibrinolytic Activity of Reparative Connective Tissue. J Pathol Bacteriol 1964;87:409-414

60 Kwaan HC, Astrup T. Localization of Fibrinolytic Activity in Myocardial Infarcts in Rats. Thromb Diath Haemorrh 1964; 12:407-417

61 Kwaan HC, Astrup T. Fibrinolytic activity in thrombosed veins. Circ Res 1965;17(6):477-483

62 Kwaan HC, Astrup T. Fibrinolytic activity in human atherosclerotic coronary arteries. Circ Res 1967;21(6):799-804

63 Kwaan HC, Albrechtsen OK. Histochemical study of fibrinolytic activity in the rat uterus in normal and hormonally induced estrus. Am J Obstet Gynecol 1966;95(4):468-473

64 Kwaan H, Markus G. Cell biology of fibrinolysis. Tenth International Congress on Fibrinolysis. August 1990. Semin Thromb Hemost 1991;17(3):159-312

65 Kwaan HC. The biologic role of components of the plasminogenplasmin system. Prog Cardiovasc Dis 1992;34(5):309-316

66 Castellino FJ, Violand BN. The fibrinolytic system-basic considerations. Prog Cardiovasc Dis 1979;21(4):241-254

67 Ploug M, Rønne E, Behrendt N, Jensen AL, Blasi F, Danø K. Cellular receptor for urokinase plasminogen activator. Carboxyl-terminal 
processing and membrane anchoring by glycosyl-phosphatidylinositol. J Biol Chem 1991;266(3):1926-1933

68 Cesarman GM, Guevara CA, Hajjar KA. An endothelial cell receptor for plasminogen/tissue plasminogen activator (t-PA). II. Annexin II-mediated enhancement of t-PA-dependent plasminogen activation. J Biol Chem 1994;269(33):21198-21203

69 Hajjar KA, Jacovina AT, Chacko J. An endothelial cell receptor for plasminogen/tissue plasminogen activator. I. Identity with annexin II. J Biol Chem 1994;269(33):21191-21197

70 Hajjar KA, Menell JS. Annexin II: a novel mediator of cell surface plasmin generation. Ann N Y Acad Sci 1997;811:337-349

71 Miles LA, Parmer RJ. Plasminogen receptors: the first quarter century. Semin Thromb Hemost 2013;39(4):329-337

72 O'Connell PA, Madureira PA, Berman JN, Liwski RS, Waisman DM. Regulation of S100A10 by the PML-RAR- $\alpha$ oncoprotein. Blood 2011;117(15):4095-4105

73 Loskutoff DJ, van Mourik JA, Erickson LA, Lawrence D. Detection of an unusually stable fibrinolytic inhibitor produced by bovine endothelial cells. Proc Natl Acad Sci USA 1983;80(10):2956-2960

74 Nielsen LS, Lecander I, Andreasen PA, Henschen A, Astedt B, Danø K. Plasminogen activator inhibitors from placenta and fibrosarcoma cells are antigenically different as evaluated with monoclonal and polyclonal antibodies. Thromb Res 1987;46(3):411-423

75 Lecander I, Astedt B. Specific plasminogen activator inhibitor of placental type PAI 2 occurring in amniotic fluid and cord blood. J Lab Clin Med 1987;110(5):602-605

76 Heeb MJ, España F, Geiger M, Collen D, Stump DC, Griffin JH. Immunological identity of heparin-dependent plasma and urinary protein $\mathrm{C}$ inhibitor and plasminogen activator inhibitor-3. J Biol Chem 1987;262(33):15813-15816

77 Strickland S, Reich E, Sherman MI. Plasminogen activator in early embryogenesis: enzyme production by trophoblast and parietal endoderm. Cell 1976;9(2):231-240

78 Strickland S, Beers WH. Studies on the role of plasminogen activator in ovulation. In vitro response of granulosa cells to gonadotropins, cyclic nucleotides, and prostaglandins. J Biol Chem 1976;251(18):5694-5702

79 Beers WH, Strickland S, Reich E. Ovarian plasminogen activator: relationship to ovulation and hormonal regulation. Cell 1975; 6(3):387-394

80 Friedman GC, Seeds NW. Tissue plasminogen activator expression in the embryonic nervous system. Brain Res Dev Brain Res 1994;81(1):41-49

81 Reddington M, Haas C, Kreutzberg GW. The plasminogen activator system in neurons and glia during motoneuron regeneration. Neuropathol Appl Neurobiol 1994;20(2):188-190

82 Melchor JP, Strickland S. Tissue plasminogen activator in central nervous system physiology and pathology. Thromb Haemost 2005;93(4):655-660

83 Strickland S. Tissue plasminogen activator in nervous system function and dysfunction. Thromb Haemost 2001;86(1):138-143

84 Schaefer U, Machida T, Vorlova S, Strickland S, Levi R. The plasminogen activator system modulates sympathetic nerve function. J Exp Med 2006;203(9):2191-2200

85 Jiang Q Yasothornsrikul S, Taupenot L, Miles LA, Parmer RJ. The local chromaffin cell plasminogen/plasmin system and the regulation of catecholamine secretion. Ann N Y Acad Sci 2002;971:445-449

86 Syrovets T, Lunov O, Simmet T. Plasmin as a proinflammatory cell activator. J Leukoc Biol 2012;92(3):509-519

87 Rømer J, Bugge TH, Pyke C et al. Plasminogen and wound healing. Nat Med 1996;2(7):725

88 Creemers E, Cleutjens J, Smits J et al. Disruption of the plasminogen gene in mice abolishes wound healing after myocardial infarction. Am J Pathol 2000;156(6):1865-1873

89 Suelves M, Vidal B, Ruiz V et al. The plasminogen activation system in skeletal muscle regeneration: antagonistic roles of urokinase-type plasminogen activator (UPA) and its inhibitor (PAI-1). Front Biosci 2005;10:2978-2985
90 Kwaan HC, Keer HN. Fibrinolysis and cancer. Semin Thromb Hemost 1990;16(3):230-235

91 Kwaan HC. The plasminogen-plasmin system in malignancy Cancer Metastasis Rev 1992;11(3-4):291-311

92 Danø K, Behrendt N, Høyer-Hansen G et al. Plasminogen activation and cancer. Thromb Haemost 2005;93(4):676-681

93 Nicholl SM, Roztocil E, Davies MG. Plasminogen activator system and vascular disease. Curr Vasc Pharmacol 2006;4(2):101-116

94 Collen D, Lijnen HR. Thrombolytic agents. Thromb Haemost 2005; 93(4):627-630

95 Sherry S. The fibrinolytic activity of streptokinase activated human plasmin. J Clin Invest 1954;33(7):1054-1063

96 Collen D. The plasminogen (fibrinolytic) system. Thromb Haemost 1999;82(2):259-270

97 Kwaan HC, Markus G. Cell biology of fibrinolysis. Semin Thromb Hemost 1991;17:161-312

98 Kwaan HC, Mazar AP. Biologic role of the plasminogen-plasmin system: thrombolysis, bleeding, and beyond. Semin Thromb Hemost 2013;39(4):327-328

99 Carrel A, Burrows MT. Cultivation in Vitro of Malignant Tumors. J Exp Med 1911;13(5):571-575

100 Ossowski L, Quigley JP, Kellerman GM, Reich E. Fibrinolysis associated with oncogenic transformation. Requirement of plasminogen for correlated changes in cellular morphology, colony formation in agar, and cell migration. J Exp Med 1973;138(5): 1056-1064

101 Astedt B, Holmberg L. Immunological identity of urokinase and ovarian carcinoma plasminogen activator released in tissue culture. Nature 1976;261(5561):595-597

102 Kwaan HC, McMahon B. The role of plasminogen-plasmin system in cancer. Cancer Treat Res 2009;148:43-66

103 Kwaan HC, Mazar AP, McMahon BJ. The apparent uPA/PAI-1 paradox in cancer: more than meets the eye. Semin Thromb Hemost 2013;39(4):382-391

104 Duffy MJ. The urokinase plasminogen activator system: role in malignancy. Curr Pharm Des 2004;10(1):39-49

105 Duffy MJ. Urokinase plasminogen activator and its inhibitor, PAI1 , as prognostic markers in breast cancer: from pilot to level 1 evidence studies. Clin Chem 2002;48(8):1194-1197

106 Look M, van Putten W, Duffy M et al. Pooled analysis of prognostic impact of uPA and PAI-1 in breast cancer patients. Thromb Haemost 2003;90(3):538-548

107 Jänicke F, Prechtl A, Thomssen C et al; German NO Study Group. Randomized adjuvant chemotherapy trial in high-risk, lymph node-negative breast cancer patients identified by urokinasetype plasminogen activator and plasminogen activator inhibitor type $1 \mathrm{~J}$ Natl Cancer Inst 2001;93(12):913-920

108 Harbeck N, Schmitt M, Paepke S, Allgayer H, Kates RE. Tumorassociated proteolytic factors UPA and PAI-1: critical appraisal of their clinical relevance in breast cancer and their integration into decision-support algorithms. Crit Rev Clin Lab Sci 2007;44(2): 179-201

109 Harris L, Fritsche H, Mennel R et al; American Society of Clinical Oncology. American Society of Clinical Oncology 2007 update of recommendations for the use of tumor markers in breast cancer. J Clin Oncol 2007;25(33):5287-5312

110 Annecke K, Schmitt M, Euler U et al. uPA and PAI-1 in breast cancer: review of their clinical utility and current validation in the prospective NNBC-3 trial. Adv Clin Chem 2008;45:31-45

111 Duffy MJ, Duggan C. The urokinase plasminogen activator system: a rich source of tumour markers for the individualised management of patients with cancer. Clin Biochem 2004;37(7): 541-548

112 Duffy MJ, Sturgeon C, Lamerz R et al. Tumor markers in pancreatic cancer: a European Group on Tumor Markers (EGTM) status report. Ann Oncol 2010;21(3):441-447

113 Schmitt M, Harbeck N, Brünner N et al. Cancer therapy trials employing level-of-evidence-1 disease forecast cancer 
biomarkers UPA and its inhibitor PAI-1. Expert Rev Mol Diagn 2011;11(6):617-634

114 Cantero D, Friess H, Deflorin J et al. Enhanced expression of urokinase plasminogen activator and its receptor in pancreatic carcinoma. Br J Cancer 1997;75(3):388-395

115 Gutova M, Najbauer J, Gevorgyan A et al. Identification of uPARpositive chemoresistant cells in small cell lung cancer. PLoS ONE 2007;2(2):e243

116 Soff GA, Sanderowitz J, Gately S et al. Expression of plasminogen activator inhibitor type 1 by human prostate carcinoma cells inhibits primary tumor growth, tumor-associated angiogenesis, and metastasis to lung and liver in an athymic mouse model. J Clin Invest 1995;96(6):2593-2600

117 Rabbani SA, Ateeq B, Arakelian A et al. An anti-urokinase plasminogen activator receptor antibody (ATN-658) blocks prostate cancer invasion, migration, growth, and experimental skeletal metastasis in vitro and in vivo. Neoplasia 2010;12(10):778-788

118 Meyer JE, Brocks C, Graefe H et al. The Oral Serine Protease Inhibitor WX-671 - First Experience in Patients with Advanced Head and Neck Carcinoma. Breast Care (Basel) 2008;3(s):20-24

119 Heinemann VEM, Pinter T, Mala C, Nevile N, Bevan P. Randomized Phase II trial with an UPA inhibitor (WX-671) in patients with locally advanced non-metastatic pancreatic cancer. European Society of Medical Oncology (ESMO) 2010:Abstract 7120D

120 Goldstein LJ OC, Heinrich B, et al. A randomized double-blind phase II study of the combination of WX-671 plus capecitabine vs. capecitabine monotherapy in first-line HER-2 negative metastatic breast cancer (MBC). Cancer Res 2012;72(Suppl 24):P5-20-21

121 Garner RL, Tillett WS. Biochemical studies on the fibrinolytic activity of hemolytic streptococci: I. isolation and characterization of fibrinolysin. J Exp Med 1934;60(2):239-254

122 Garner RL, Tillett WS. Biochemical Studies on the Fibrinolytic Activity of Hemolytic Streptococci: Ii. Nature of the Reaction. J Exp Med 1934;60(2):255-267

123 Johnson AJ, Tillett WS. The lysis in rabbits of intravascular blood clots by the streptococcal fibrinolytic system (streptokinase). J Exp Med 1952;95(5):449-464

124 Nydick I, Ruegsegger P, Abarquez R, Cliffton EE, Ladue JS. The effect of fibrinolytic agents on myocardial infarction. Prog Cardiovasc Dis 1960;3:13-28

125 Clarke RL, Cliffton EE. The treatment of cerebrovascular thromboses and embolism with fibrinolytic agents. Am J Cardiol 1960; 6:546-551

126 Sherry S, Alkjaersig N. Biochemical experimental, and clinical studies of proteolytic enzymes with particular reference to the fibrinolytic enzyme of human plasma. Ann N Y Acad Sci 1957; 68(1):52-66
127 Ambrus JL, Ambrus CM, Back N, Sokal JE, Collins GL. Clinical and experimental studies on fibrinolytic enzymes. Ann N Y Acad Sci 1957;68:97-136, discussion 136-137

128 Fletcher AP, Sherry S, Alkjaersig N, Smyrniotis FE, Jick S. The maintenance of a sustained thrombolytic state in man. II. Clinical observations on patients with myocardial infarction and other thromboembolic disorders. J Clin Invest 1959;38(7):1111-1119

129 Johnson AJ, McCARTY WR. The lysis of artificially induced intravascular clots in man by intravenous infusions of streptokinase. J Clin Invest 1959;38:1627-1643

130 Kaste M. Stroke: advances in thrombolysis. Lancet Neurol 2013; 12(1):2-4

131 del Zoppo GJ. Plasminogen activators and ischemic stroke: conditions for acute delivery. Semin Thromb Hemost 2013;39(4): 406-425

132 Boucek RJ, Murphy WP Jr. Segmental perfusion of the coronary arteries with fibrinolysin in man following a myocardial infarction. Am J Cardiol 1960;6:525-533

133 Dotter CT, Rösch J, Seaman AJ. Selective clot lysis with low-dose streptokinase. Radiology 1974;111(1):31-37

134 Oklu R, Wicky S. Catheter-directed thrombolysis of deep venous thrombosis. Semin Thromb Hemost 2013;39(4):446-451

135 Wicky S, Pinto EG, Oklu R. Catheter-directed thrombolysis of arterial thrombosis. Semin Thromb Hemost 2013;39(4):441-445

136 Van De Craen B, Declerck PJ, Gils A. The Biochemistry, Physiology and Pathological roles of PAI-1 and the requirements for PAI-1 inhibition in vivo. Thromb Res 2012;130(4):576-585

137 Vaughan DE. PAI- 1 antagonists: the promise and the peril. Trans Am Clin Climatol Assoc 2011;122:312-325

138 Vaughan DE, De Taeye BM, Eren M. PAI-1 antagonists: predictable indications and unconventional applications. Curr Drug Targets 2007;8(9):962-970

139 Declerck PJ, Gils A. Three decades of research on plasminogen activator inhibitor-1: a multifaceted serpin. Semin Thromb Hemost 2013;39(4):356-364

140 Van De Craen B, Scroyen I, Vranckx C, et al. Maximal PAI-1 inhibition in vivo requires neutralizing antibodies that recognize and inhibit glycosylated PAI-1. Thromb Res 2012;129(4): e126-e133

141 Izuhara Y, Yamaoka N, Kodama H, et al. A novel inhibitor of plasminogen activator inhibitor-1 provides antithrombotic benefits devoid of bleeding effect in nonhuman primates. J Cereb Blood Flow Metab 2010;30(5):904-912

142 Yamaoka N, Kawano Y, Izuhara Y, Miyata T, Meguro K. Structureactivity relationships of new 2-acylamino-3-thiophenecarboxylic acid dimers as plasminogen activator inhibitor-1 inhibitors. Chem Pharm Bull (Tokyo) 2010;58(5):615-619 